\title{
BIOGAS PRODUCTION POTENTIAL OF SELECT RAW MATERIALS COMMONLY FOUND IN HOUSE HOLD WASTE
}

\author{
M.P.P.R. Kumara and S. Wijetunga* \\ Department of Agric Engineering,University of Ruhuna, Sri Lanka \\ * E-mail- swije@ ageng.ruh.ac.lk. Tel- ++94412292200 Fax- ++94412292384
}

\begin{abstract}
Most of the people in Sri Lanka do not have enough and distinct knowledge about biogas technology, suitable raw materials and biogas production potential of such raw materials. In this study, evaluate the composition, physical and chemical properties of house hold waste, and to determine the biogas production potential of selected raw materials. After evaluating the selected raw materials, biogas production potential was determined. News papers, papaya peels ,banana peels, coconut scraped refuses, potato refuses, rice, and mixture of those waste were fed into the batch digesters $(4.5 \mathrm{~L})$ with inoculums and sealed to maintain anaerobic condition. Each treatment comprised $400 \mathrm{~g}$ of raw materials (dry weight). C:N ratio of each treatment was adjusted before sealing the reactors. Daily biogas productions of every treatment were recorded and $\mathrm{pH}$ adjustment was done where necessary in all reactors. Gas production started in all the reactors 16 days after filling. Highest gas production $(10473.1 \mathrm{~mL})$ was observed in reactors having mixtures of wastes during 41 days while lowest gas production $(754 \mathrm{~mL})$ was recorded in reactors with coconut scrap refuses in 27 days. Average duration of gas production for most of the waste was 54 days. $\mathrm{pH}$ was reduced in the mixture of reactors at the beginning down to 3.91 and it was adjusted to improve the gas production. Papaya peel and coconut scrap were the highest and lowest degradability waste respectively. It appears that this technology is a good option for the management of the organic fraction of household waste.
\end{abstract}

Keywords: Biogas: Anaerobic Digestion, Household Waste, Waste Management

\section{INTRODUCTION}

Biogas has been a reasonably successful renewable energy technology developed and widely disseminated worldwide. Biogas can be produced by anaerobic digestion of organic matter and it is an environmentally friendly way to convert organic wastes into burning gas. Anaerobic digestion provides some possibilities and solutions to such global concerns as alternative energy production, handling human, animal, municipal, industrial and house wastes safely, controlling environmental pollution, and expanding food supplies. Traditionally the biogas technology was looked at as a source of energy for the rural population mainly for lighting, though it possessed several other benefits.

The biogas technology is more popular only around areas where cow dung is available. Other organic matter sources also can digest anaerobically and produce biogas. (Pyle et al, 1979) So, most of the research and application work in this direction had been performed in many countries. Household waste is a good source of raw material suitable for biogas production. It is generated in the day to day activities in households. Management of household waste is also a major issue, and it has been for hundreds of years. Historically, people disposed of their household waste by burying or burning it, however, these methods became impractical once human populations started exploding which results the development of landfills and disposal sites where collected waste from a large area is buried. Emissions from landfill take a number of forms, gaseous emissions of volatile organic compounds, airborne particulate matter and leachate. The contamination of groundwater by landfill leachates has been also well noted (Muthupandi, 2007). In Sri Lankan context, biogas production from house hold waste could be an advantageous option. The waste recycling or waste management is not properly

Proceedings of the 15 $5^{\text {th }}$ International Forestry and Environment Symposium, 26-27 November 2010.

Published by Department of Forestry and Environmental Science, University of Sri Jayewardenepura, Sri Lanka. 
practiced in Sri Lanka. Thus biogas is a good solution for energy crisis in rural areas. Evan though, this technology is quite popular in some areas of the country, there are so many draw backs. The unavailability of the biogas generating potential of raw materials found in house hold waste can be considered as a major problem.

It was attempted to assess the biogas production potential of different types of common wastes found in household wastes (Sri Lanka), to evaluate the composition and physical and chemical properties of household wastes and to evaluate physical and chemical properties of the digested slurry.

\section{MATERIALS AND METHOD}

\subsection{COLLECTION OF WASTE}

Ten houses were randomly selected in Walasmulla area. The generated house hold waste was collected. The collected wastes were separated in to different waste categories. The composition of waste samples collected in different days was determined and then average values were calculated.

\subsection{EXPERIMENTAL PROCEDURE}

Different types of common waste found in households were anaerobically digested and biogas production was determined. News paper (NP), papaya peel (PP), coconut scrap refuse (CS), banana peel $(\mathrm{BP})$, rice $(\mathrm{R})$, potato discards $(\mathrm{PD})$ and mixture of those waste $(\mathrm{MI})$ were used as raw materials for the study. Three replicates for each treatment were used.

\subsection{CONSTRUCTION OF REACTOR SYSTEM}

Plastic cans of $4.5 \mathrm{~L}$ were used as batch reactors for the study. The generated biogas was measured using water replacement method. The reactor system and biogas measurement apparatus are shown in figure 1.

\subsection{FILLING THE REACTOR WITH RAW MATERIALS}

Two hundred and fifty grams of dry matter of each waste material were filled into digesters and $25 \mathrm{~g}$ of cow dung was also applied to each digester as inoculums. Total solid content of all treatment was adjusted to $\sim 11 \%$ by adding required amount of water.

\subsection{BIOGAS MEASUREMENT \& pH ADJUSTMENT}

Biogas production was measured daily by using water replacement method. The $\mathrm{pH}$ of each reactor was recorded once a week and it was adjusted to $\sim 6$ where necessary by adding the sufficient amount of $\mathrm{NaOH}$.

\subsection{DETERMINATION OF PHYSICOCHEMICAL PROPERTIES OF DIGESTED SLURRY}

$A$ fter the biogas production of all reactors ceased, the slurry sample were withdrawn and TS, total volatile solid (TVS) ash were determined by the standard methods. The $\mathrm{pH}$ of slurry samples was also measured in the slurry of each reactor at the end of the experiment. 


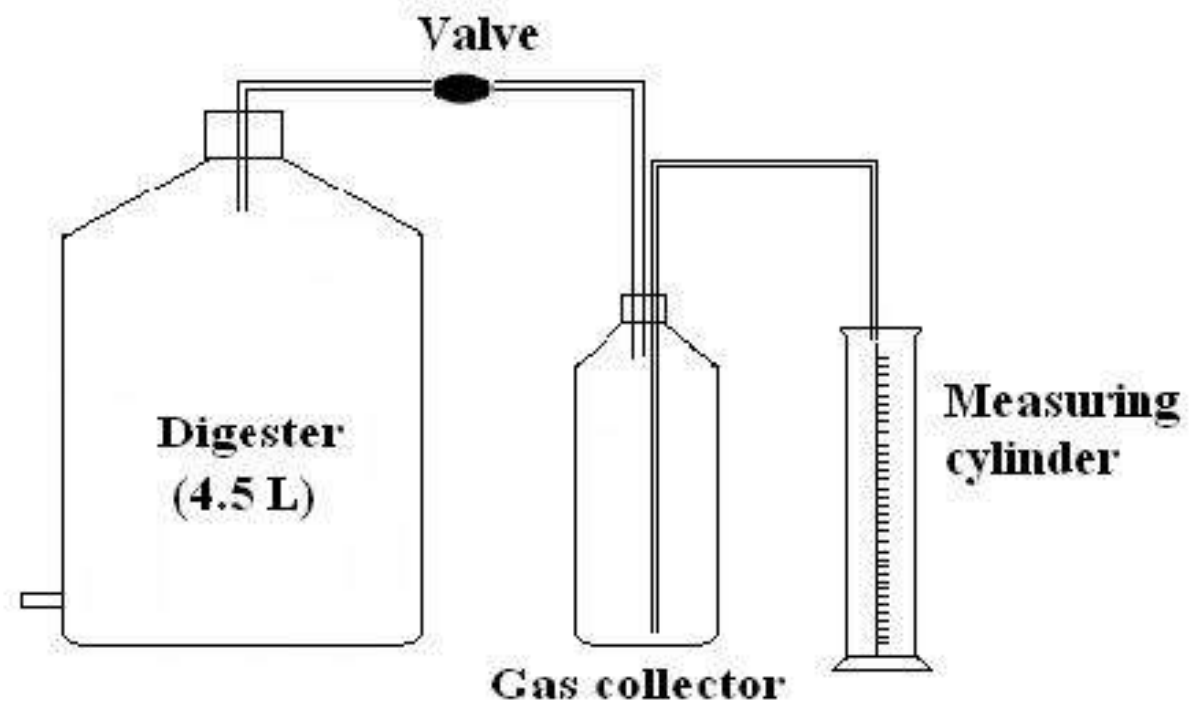

Figure 1: Reactor System with Biogas Measuring Apparatus

\section{RESULTS AND DISCUSSION}

\subsection{TS AND TVS OF DIFFERENT RAW MATERIALS}

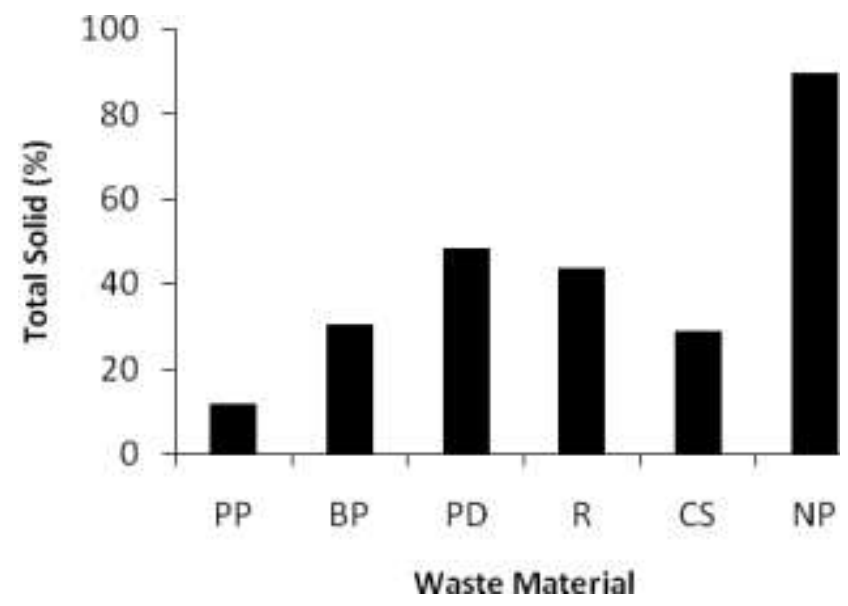

Figure 2: Total Solid of Waste Material

The total solids of the different raw materials used for the biogas measurements are shown in figure 2. The highest total solid content was observed in NP (89.51\%) and lowest total solid was determined in papaya peel (11.76\%). News papers contain more cellulose and the moisture also very low and therefore, the highest TS levels can be expected. Other raw materials are food wastes and their moisture content was comparatively higher than news papers. Total solid content of papaya feel is suitable range of anaerobic digestion (10-12\%) and TS of other materials was over $20 \%$ and less than $45 \%$ where anaerobic digestion could be performed in dry batch mode (Mathur and Rathore, 1992).

Volatile solids are important factor for biogas production. The highest TVS were shown by NP and it was $86.42 \%$. The lowest TVS was given by coconut scrap and it value was $28.83 \%$ (figure 3 ). Volatile solids directly affect to the biogas production. Wastes having higher volatile solid may produce large amount of biogas. Over $40 \%$ of TVS were given in most of the waste.

Proceedings of the 15 ${ }^{\text {th }}$ International Forestry and Environment Symposium, 26-27 November 2010.

Published by Department of Forestry and Environmental Science, University of Sri Jayewardenepura, Sri Lanka. 


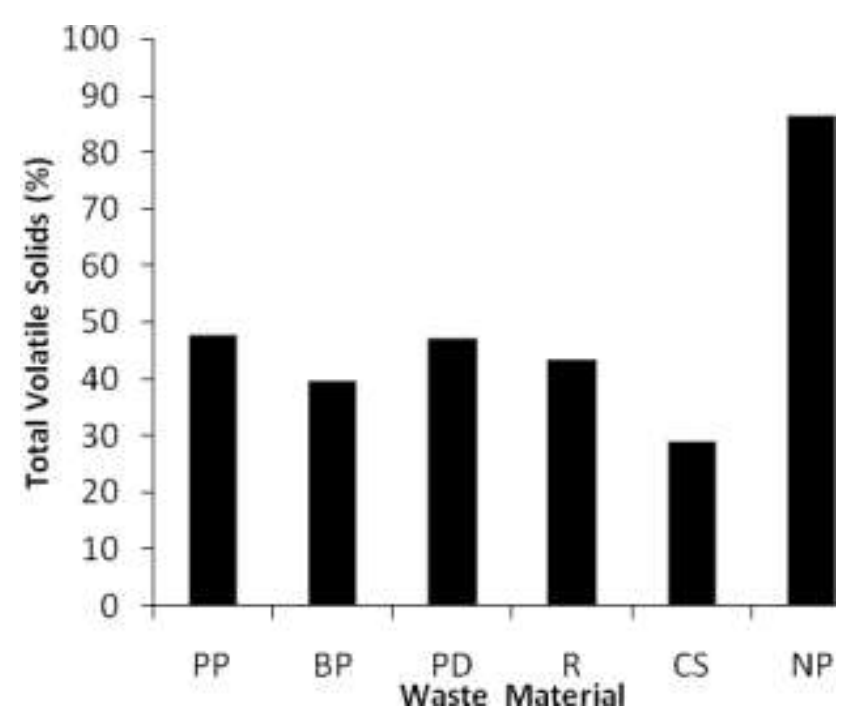

Figure 3: Volatile Solid of Waste Material

\subsection{CARBON AND NITROGEN CONTENTS OF RAW MATERIAL}

Carbon and nitrogen contents of different raw materials are shown in table1. The C:N ratio of most of raw materials used for the study are in suitable range for anaerobic digestion except news papers. The proper growth and development of microbes can be expected when C:N ratio of raw materials are in 25-30:1 (Mathur and Rathore, 1992). Therefore, in this study, it was not attempted to adjust the C:N ratio of most of the raw materials. However, C:N ratio was adjusted in NP since its Nitrogen content was very low.

Table 1: Carbon, Nitrogen and C:N ratio of raw materials

\begin{tabular}{lccc}
\hline Material & C\% & N\% & C:N Ratio \\
\hline News Paper & 72.10 & 0.1 & $721: 1$ \\
Banana Peel & 37.40 & 1.58 & $24: 1$ \\
Coconut & 16.50 & 0.68 & $24: 1$ \\
Papaya Peel & 38.10 & 1.49 & $26: 1$ \\
Rice & 41.30 & 1.23 & $34: 1$ \\
Potato & 36.40 & 1.52 & $24: 1$ \\
\hline
\end{tabular}

\subsection{BIOGAS LIBERATION FROM REACTORS}

In first stage only $250 \mathrm{~g}$ of dry materials were filled into digesters as reported in section 2.4. However, no biogas production was observed. Dry matter content is very important for biogas production. At the same time, required amount of cow dung (inoculums) is also required to initiate the anaerobic digestion process. Therefore, additional $150 \mathrm{~g}$ of (dry matter) each raw materials were added to respective reactors. Then, $25 \mathrm{~g}$ of cow dung again was also added. The final TS level of each reactor was $400 \mathrm{~g}$. After the second feeding, the biogas liberation was started in reactors after 16 days of initial filling (figure 4). 


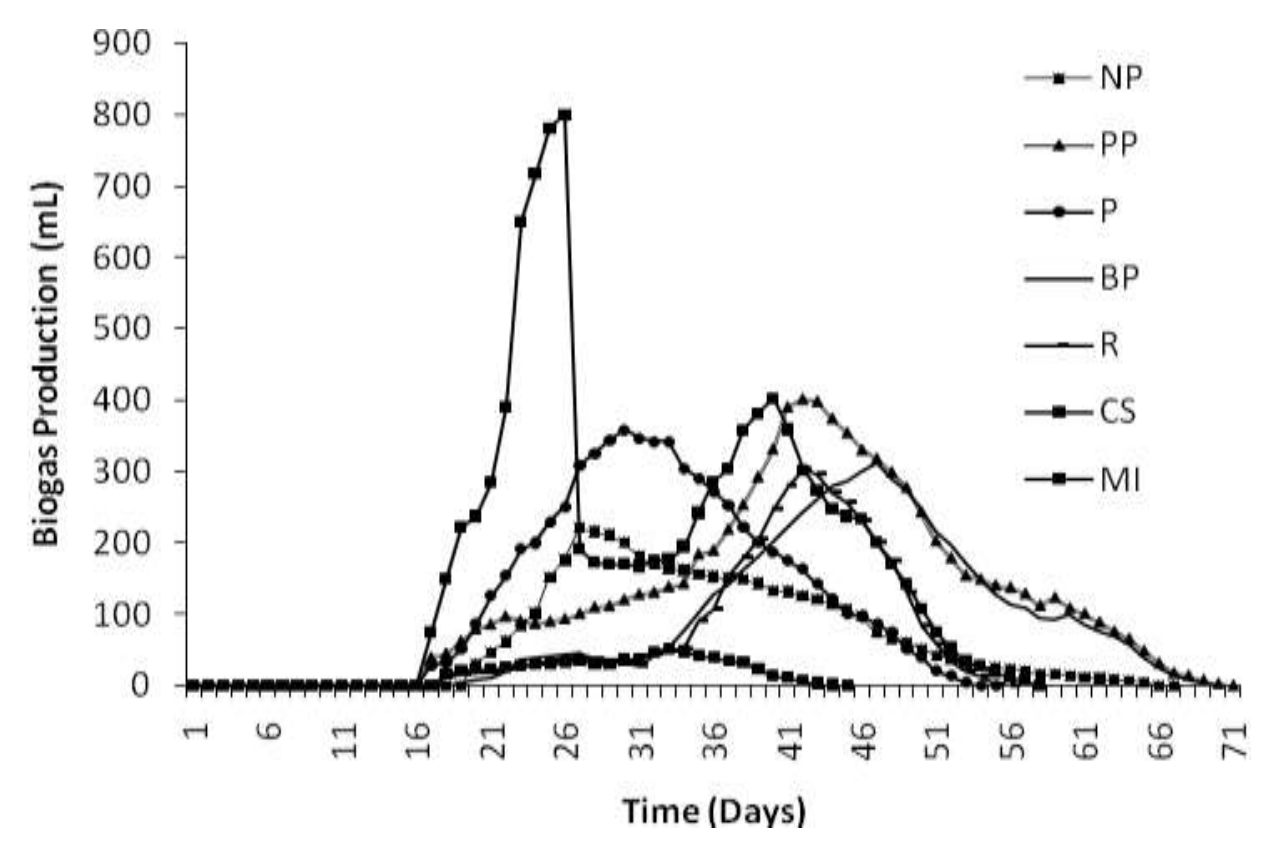

Figure 4: Daily biogas liberation from different reactors

The biogas production was observed, at first, in reactors filled with mixtures of waste. The reactors filled with papaya peel, potato discards, rice and coconut scrap started gas production $17^{\text {th }}$ days of initial feeding. The reactor filled with NP and NP started the gas production in $18^{\text {th }}$ and $19^{\text {th }}$ days, respectively. The highest daily gas production was given by the mixture of different wastes. The lowest gas production was observed by reactor filled with coconut scrap and the gas production duration was also low compared with other reactors (30 days) (figure 4 and 5). After few days (25 day), biogas production was suddenly reduce in the reactor filled with mixture of waste. The $\mathrm{pH}$ directly affects for the methane producing bacteria (Mathur and Rathore, 1992). The biogas production was inhibited and reduced or stopped when $\mathrm{pH}$ is lower than 5. This may be the reason. In anaerobic digestion process, complex compounds were hydrolyzed to simple oxidized compound such as monosaccharide, fatty acids and amino acids. These simple compounds are converted to volatile fatty acids by microbes in the second step of anaerobic digestion. The volatile fatty acids are consumed by methanogenic bacteria and as by product they produce mixture of gases called biogas. However, the accumulation of volatile fatty acids reduces the $\mathrm{pH}$ and eventually it affects to methanogenic bacteria resulting the reduction of their population (Michael, 2003). The sudden reduction of biogas production in the reactors filled with mixture of waste basically could be due to accumulation of volatile fatty acids which results the reduction of $\mathrm{pH}$.

The highest reduction of VS was noted in reactors filled with mixture of wastes (Figure 7). The reduction of VS in all reactors was quite low. It seems that still there are organic matters in reactors. Lignin and cellulose are quite resistant to anaerobic degradation (Mathur and Rathore, 1992). Therefore, in these reactors, it seems that those organic compounds may present. 


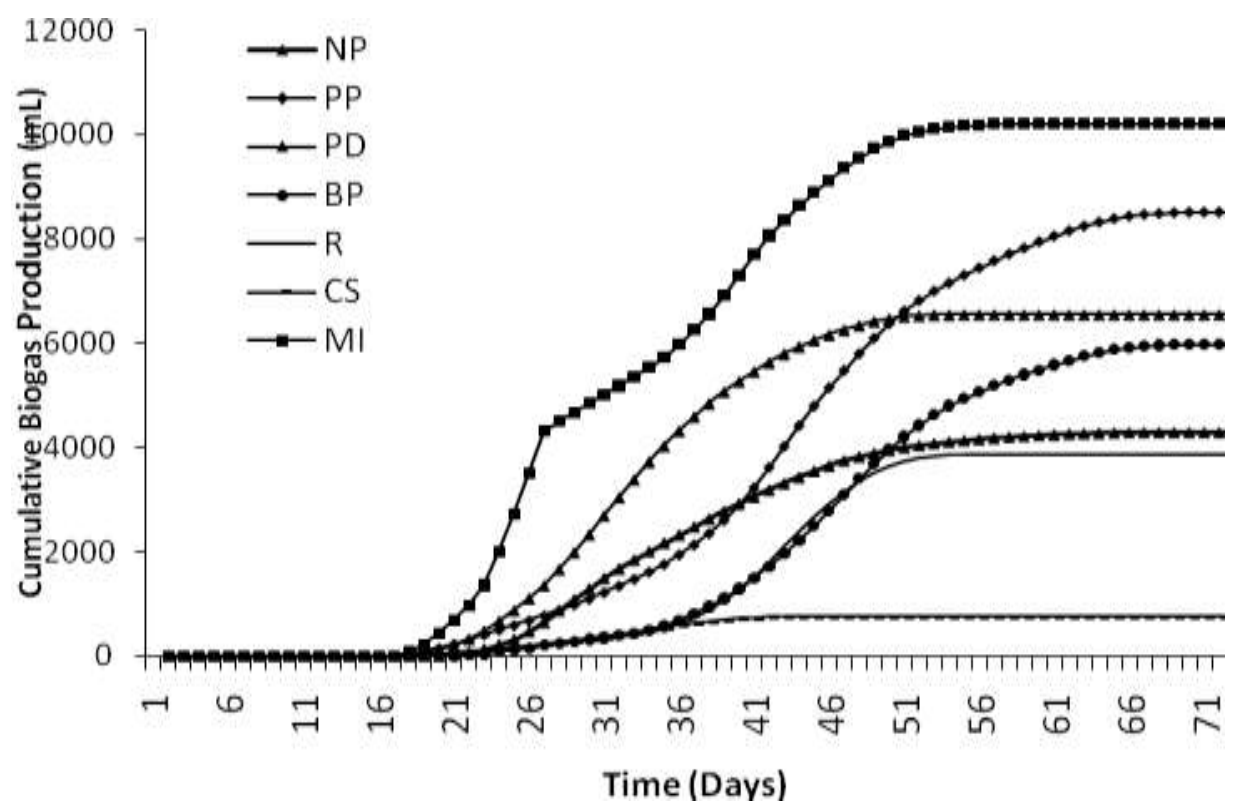

Figure 5: Cumulative biogas productions

The highest gas production rate was also observed in mixture of wastes and lowest rate was noted in reactors filled with coconut scrap discards. The lower degradability due to higher oil may be the reason for the reduction of biogas production in coconut scrap discards. Most of raw materials except coconut scrap discards produced considerable higher biogas production.

\subsection{CHANGES OF PH IN DIFFERENT REACTORS DURING STUDY}

After three weeks, the $\mathrm{pH}$ of the reactors filled with the mixture of waste reduced quickly. At the same time, biogas production also reduced. Therefore, $\mathrm{pH}$ was adjusted in using $5 \mathrm{~mol} / \mathrm{l}$ of $\mathrm{NaOH}$. Thereafter, $\mathrm{pH}$ increased a little and, however, no considerable reduction in $\mathrm{pH}$ was observed (figure 6). The $\mathrm{pH}$ in all reactors was in suitable range for biogas production (Michael, 2003).

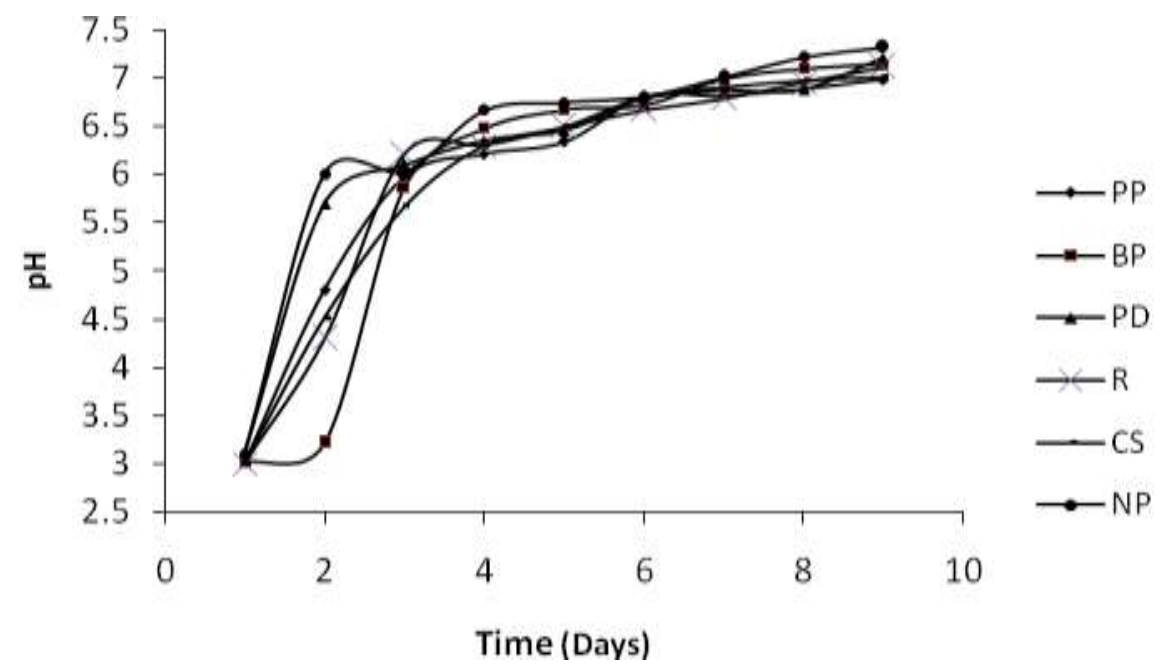

Figure 6: $\mathrm{pH}$ changes in reactors during study 


\subsection{PHYSICO-CHEMICAL PROPERTIES OF DIGESTED SLURRY}

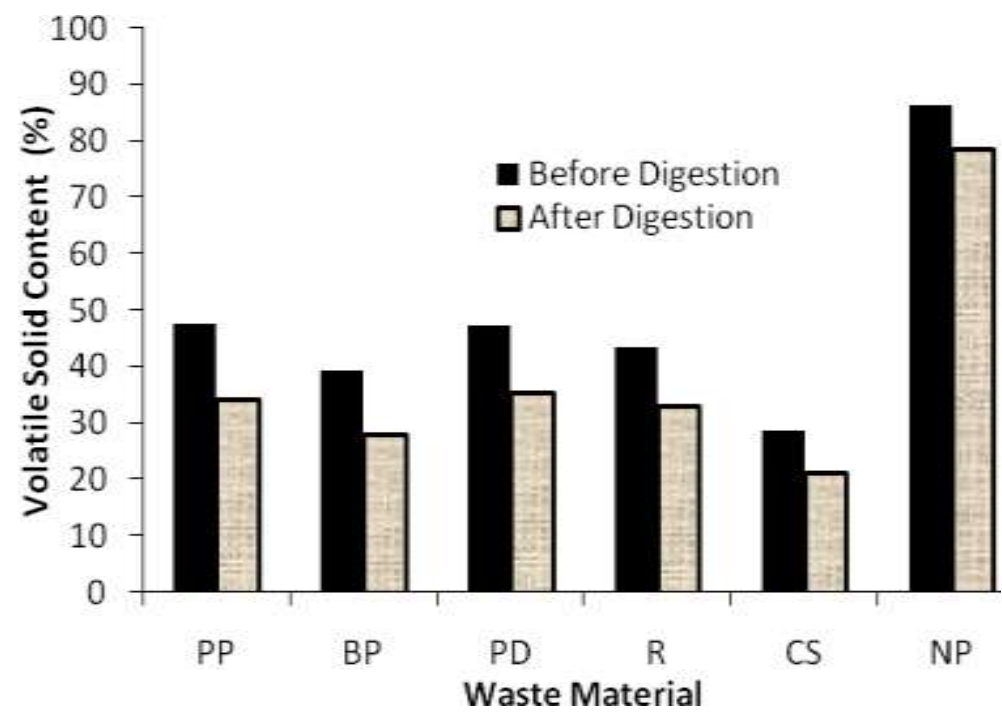

Figure 7: Volatile solids of raw materials and digested materials

\section{CONCLUSION}

According to the results obtained in this study, the most suitable raw material for biogas production is mixture of wastes. The biogas production rate of 